\title{
Effect of farmland shelterbelts on gully erosion in the black soil region of Northeast China
}

\author{
Rongxin Deng ${ }^{1} \cdot$ Wenjuan Wang ${ }^{2} \cdot$ Haiyan Fang ${ }^{3} \cdot$ Zhihong Yao $^{1}$
}

Received: 19 May 2014/Accepted: 16 September 2014/Published online: 19 July 2015

(C) Northeast Forestry University and Springer-Verlag Berlin Heidelberg 2015

\begin{abstract}
The black soil region of northeast China is one of the most important grain-producing areas in China. Increasingly severe gully erosion in this region has destroyed much farmland and reduced grain production. We analyzed SPOT5 imagery from 2007 and TM imagery from 2008 to describe the distributions of gullies and farmland shelterbelts in Kedong County and to assess the effect of farmland shelterbelts on gully erosion. The imagery revealed 2311 gullies with average density of $418.51 \mathrm{~m} \mathrm{~km}^{-2}$, indicating very serious gully erosion. With increasing slope gradient there was an inverse trend between gully density and shelterbelt density, indicating that farmland shelterbelts can prevent gully erosion. The defense effect of farmland shelterbelts against gully
\end{abstract}

Project funding: This research was supported by the National Natural Science Foundation of China (31400612, 41271305); the Key

Technologies Research and Development Program of Henan Province (142102110147).

The online version is available at http://www.springerlink.com

Corresponding editor: Zhu Hong

Haiyan Fang

fanghy@igsnrr.ac.cn

1 Institute of Resources and Environment, North China University of Water Resources and Electric Power, Zhengzhou 450045, People's Republic of China

2 Department of Resources and Environmental Sciences, Henan University of Economics and Law, Zhengzhou 450002, People's Republic of China

3 Key Laboratory of Water Cycle and Related Land Surface Processes, Institute of Geographical Sciences and Natural Resources Research, Chinese Academy of Sciences, Beijing 100101, People's Republic of China erosion varied with distance: for distances $<120 \mathrm{~m}$, the defense effect was consistent and very strong; for distances of $120-240 \mathrm{~m}$, a weak linear decrease was found in the defense effect; and for distances $>240 \mathrm{~m}$, the defense effect of the shelterbelts was significantly weaker. We recommend an optimal planting density of farmland shelterbelts for the prevention of gully erosion at $1100-1300 \mathrm{~m} \mathrm{~km}^{-2}$.

Keywords Black soil region · Gully density · Gully erosion $\cdot$ Farmland shelterbelts $\cdot$ Northeast China

\section{Introduction}

The black soil region of northeast China is one of the most important grain-producing areas in China. But increasingly serious soil erosion is an increasing challenge to the production of marketable grain, and the formation of gully systems is one sign of severe soil erosion. Gullies play an important role in the total sediment yield. Data collected from different parts of the world have shown that rates of soil loss through gully erosion a represent $10-94 \%$ of the total sediment yield due to water erosion (Krause et al. 2003; Poesen et al. 2003). Gully erosion can decrease soil productivity, interfere with farming operations, and degrade landscape quality (Capra and Scicolone 2002; Poesen et al. 2003; Foster 2005). Currently, gully erosion in the black soil region of northeast China is severe (Zhang et al. 2007b; Wu et al. 2008). Shen et al. (2003) determined that the total number of gullies was about 250,000 and that the area of farmland eroded by gullies was up to 400,000 ha. In the black soil region of northeast China, the total loss of food production caused by gully erosion has been estimated at 1.4 billion $\mathrm{kg}$. To 
protect the black soil and to ensure food safety and sustainable development within this region, considerable scientific research has been performed on gully erosion. Some research focused on the growth mechanisms of gullies on sloping cultivated land, considering factors such as rainfall, farming practices, and seasonal differences (Meng and Li 2009; Zhang et al. 2008). Other research considered the spatial morphological characteristics and formational causes of gullies, and soil loss through gully erosion by monitoring several to dozens of small-scale gullies over 3-5 years with the support of Geographic Information Systems (GIS), Global Positioning System (GPS), and traditional measurement techniques (Zhang et al. 2007b; Wu et al. 2008; Dong and Wu 2010). Additionally, other work discussed the spatial distribution characteristics, patterns, and dynamic changes of gully erosion at large scale (Yan et al. 2010; Wang et al. 2012a, b). All these investigations have provided a good theoretical and practical foundation for the study of gully erosion.

Farmland shelterbelts in northeast China are an important part of the "Three Norths" forest protection system. In 1978, the Central Committee of the Communist Party of China embarked on a re-vegetation project known as the "Three Norths" (referring to the northwest, the north, and the northeast of China).One of the main biological strategies of this project was to establish shelterbelts for farmland and pasture (Richard and Robyn 1990). As an important part of forestry eco-engineering, farmland shelterbelts are significant in controlling desertification, improving farm production, establishing a new ecological balance, and developing regional economies. Farmland shelterbelts can play a positive role in the prevention and control of soil erosion by improving soil, conserving water, regulating runoff, and reducing sediment (Chen et al. 2010; Ma et al. 2010; Shi et al. 2010). Although farmland shelterbelts can prevent erosion, there have been few studies regarding soil erosion and shelterbelts in the black soil region of northeast China. Only a few studies have investigated the effects of shelterbelt distribution on gullies and these considered small-scale watersheds of only $3-4 \mathrm{~km}^{2}$ (Su et al. 2012a, b). There have been no large-scale studies on gullies and shelterbelts.

We used GIS and SPOT5 imagery from 2007 and TM imagery from 2008 to plot and measure the spatial distributions of gullies and shelterbelts in the black soil region of northeast China. We used this information to analyze the large-scale effects of farmland shelterbelts on gully erosion. The objectives of our study were to describe how shelterbelts prevent gully erosion, and to provide a scientific basis for the control of gully erosion and sustainable development within this region.

\section{Materials and methods}

\section{The study area}

This study was conducted in Keshan County, Heilongjiang Province, China $\left(47^{\circ} 42^{\prime}-48^{\circ} 34^{\prime} \mathrm{N}, \quad 125^{\circ} 07^{\prime}-126^{\circ} 44^{\prime} \mathrm{E}\right.$; Fig. 1). Keshan County covers an area of $3389 \mathrm{~km}^{2}$ with average elevation of $236 \mathrm{~m}$, and mean slope gradient of $2.5 \%$ (range 0-28.9\%). The climate is semi-humid and continental with a long and cold winter. Mean January and July temperatures are -22.7 and $21.3{ }^{\circ} \mathrm{C}$, respectively. Mean annual precipitation is $510 \mathrm{~mm}$ with high-intensity rainstorms in summer.

The main soil type is Luvic Phaeozem in the FAO/ UNESCO system (Zhang et al. 2007a, b). The parent materials of the phaeozem are quaternary lacustrine and fluvial sand beds or loess sediments (Sun and Liu 2001). The main textural classes of the top soil are silt clay loam to clay loam (Wu et al. 2008). This kind of soil texture is highly erodible (Torri et al. 1997), and the soil erodibility is even larger than that of the loess soil on China's Loess Plateau (Zhang et al. 2007a, b).

Historically, most of the land within the region was covered by shrubby woodland but with increasing population, large-scale land reclamation has been undertaken since the establishment of the People's Republic of China in 1949. The major crop is soybean, in rotation with wheat and corn. Farmland shelterbelts have been constructed since the 1970s. Initially, they were intended to protect crops from drought- and wind-induced damage. For the convenience of mechanized cultivation, tillage direction is usually parallel to the farmland shelterbelts. However, when this calls for downslope cultivation, it accelerates soil erosion and thus, farmland shelterbelts can have considerable effects on soil erosion.

\section{Gully data}

Gullies are commonly defined as channels that are so deep they cannot be removed by normal soil tillage. However, there are other definitions such as that of a channel having a cross-sectional area $>1 \mathrm{ft}^{2}\left(=929 \mathrm{~cm}^{2}\right)$ (Hauge 1977; Poesen 1993). In application, the terms gully (permanent gully), ephemeral gully, and rill are often used interchangeably (Bull and Kirkby 1997). However, in this paper, the object of study is a gully (permanent gully) that can be clearly identified on a SPOT5 image.

In this study, gully distribution data were obtained from 2.5-m-resolution SPOT5 imagery obtained on August 28, 2007. The gullies were recognized according to their spectral characteristics, following which field surveys were conducted during 2008-2009. The main survey elements 


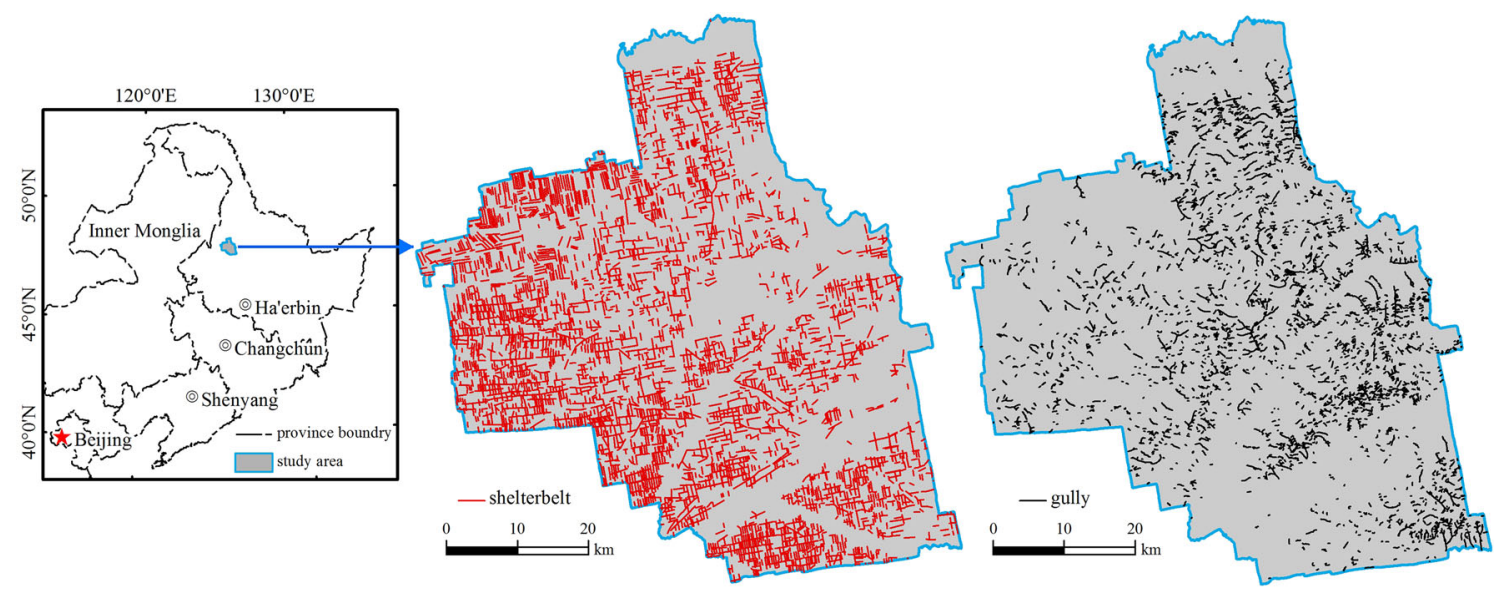

Fig. 1 Location of the study area, and distributions of farmland shelterbelts and gullies

included agrotype, lithology, land use, gully depth, width, and length, deposit in the gully bottom, and the growth of vegetation in and around the gullies. After completion of the field survey, based on the theories of gully growth and classification (Yang 2001; Yu and $\mathrm{Wu} 2003$ ) and with the help of expert knowledge, the indicators for gully interpretation were determined. Finally, using the ArcGIS 10.0 software platform combined with expert experience, reference to topographic maps, and other related information, the data of gully distribution were acquired. Validation work was undertaken for 3 days in 2009, based on which the gully data were modified and the final gully distribution data obtained (Fig. 1). The validation revealed that the precision of gully interpretation was $>95 \%$.

\section{Shelterbelt data}

A TM image from June 12, 2008 was used to acquire the shelterbelt data. The method used the blue $(450-495 \mathrm{~nm})$, green $(495-590 \mathrm{~nm})$, and red $(620-750 \mathrm{~nm})$ portions of the electromagnetic spectrum to compose a standard falsecolor composite image. The features of the farmland shelterbelts were clearly identifiable from the TM images as linear, red, regular structures. Here, the indicators for the farmland shelterbelts were initially established according to field investigation. Then, using ArcGIS 10.0 software, the farmland shelterbelts data were acquired based on the human-computer interactive interpretation method. Finally, field validation was performed in mid-September 2008 and because of the distinctive characteristics of farmland shelterbelts, the precision was found to be $>97 \%$.

\section{Land use data}

The data source used to acquire land use information was a TM image from June 12, 2008. First, the image was geo- referenced to a relief map. Then, the data were preprocessed (e.g., re-projection, histogram equalization) using ERDAS Imagine version 9.1; the Albers Conical Equal Area was used as the re-projection coordinate system. According to the characteristics of the image, expert knowledge, field data, the second Chinese land investigation interpretation standard, and other related geographic maps, the indicators for land use interpretation were established. Using the ArcGIS 10.0 platform and the human-computer interactive method, the TM image was interpreted and land uses were grouped into six types: cultivated land, forest, grassland, water bodies, built-up land, and marsh (Fig. 2). Data accuracy was assessed by performing field surveys: compared with the field data, the total precision was no lower than $90 \%$.

\section{Terrain data}

For the DEM data, contour and spot elevation data were obtained by digitizing topographic maps in ArcGIS 10.0. Then, taking the digital contours and spot elevations as input data and using TOPGRID arithmetic software, the study area DEM with 30-m spatial resolution was created. Using the ArcGIS 10.0 spatial analysis module, the slopes and slope lengths were extracted from the DEM.

\section{Spatial analysis methods}

The densities of the gullies and shelterbelts were obtained using the method outlined below. First, the study area was divided into 48 grids with $10 \times 10 \mathrm{~km}$ resolution. Then, the densities of the gullies and shelterbelts in each grid were counted, and their density values given to the center point of each grid. Finally, using the center point, the spatial distributions of the gully and shelterbelt densities were interpolated with $30 \times 30 \mathrm{~m}$ resolution using the spatial analysis module of ArcGIS 10.0 (Fig. 3). 


\section{Results and discussion}

\section{Characteristics of gully erosion and farmland shelterbelts}

The total number of farmland shelterbelts was 5279 with total length of about $3775 \mathrm{~km}$, giving an average shelterbelt density of $1113.73 \mathrm{~m} \mathrm{~km}^{-2}$. In contrast, the total number of gullies was 2311 with total length of about $1419 \mathrm{~km}$, giving an average density of $418.51 \mathrm{~m} \mathrm{~km}^{-2}$ (Fig. 1). Related research in the adjacent Kedong County of the black soil region of northeast China found 2246 gullies with an average density of $479.15 \mathrm{~m} \mathrm{~km}^{-2}$ (Wang et al. 2010), indicating gully erosion of very similar extent to that of the current study.

Farmland shelterbelts are artificial ecological systems that have high planting density and considerable length to achieve the biological objectives of the "Three Norths" program. However, a comparison of gullies and farmland shelterbelts shows that gully erosion is a very serious problem. Figure 3 shows that shelterbelt density increases from the northeast to the southwest with the highest density of $>1400 \mathrm{~m} \mathrm{~km}^{-2}$ found in the west and southwest of the region. Conversely, the trend of change in gully density shows a decrease from the northeast to the southwest with the highest density of $>800 \mathrm{~m} \mathrm{~km}^{-2}$ found in the northeast. Generally, shelterbelt density of $>600 \mathrm{~m} \mathrm{~km}^{-2}$ accounts for $78.35 \%$ of the total area, and density of $800-1000 \mathrm{~m} \mathrm{~km}^{-2}$ accounts for $24.11 \%$ of the total area (Table 1). In contrast, gully density of $200-800 \mathrm{~m} \mathrm{~km}^{-2}$ accounts for $91.70 \%$ of the total area, and gully densities of $200-400,400-600$, and $600-800 \mathrm{~m} \mathrm{~km}^{-2}$ account for $1152.89,828.36$, and $1126.49 \mathrm{~km}^{2}$, or $34.02,24.44$, and $33.24 \%$, respectively, of the total area. Compared with the

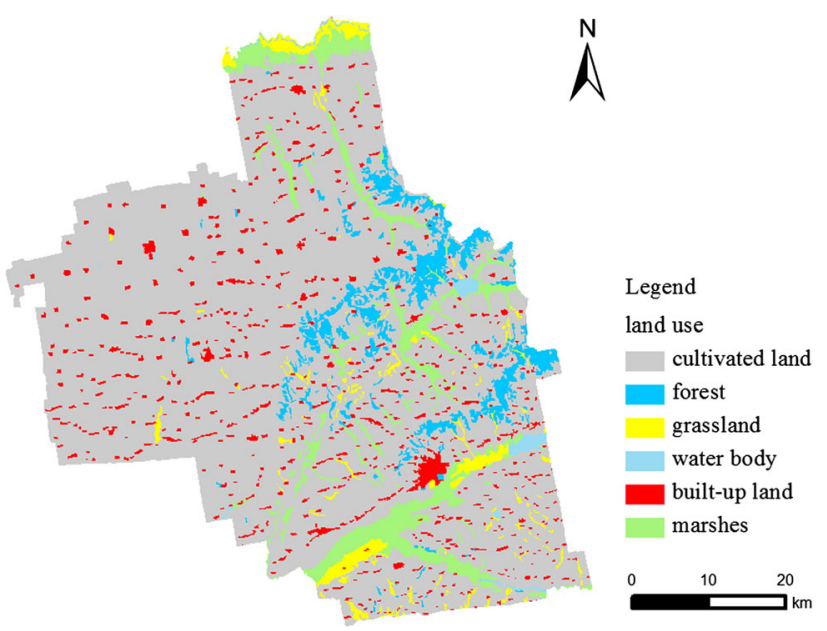

Fig. 2 Distribution and composition of land use in 2008 in the study area artificial shelterbelt ecosystems, the above results show that gully erosion in the black soil region of northeast China is a very serious problem for which controlling measures must be taken.

According to the land use data in 2008 (Fig. 2), the proportions of cultivated land, forest, grassland, water bodies, built-up land, and marsh were $80.00,5.17,2.78$, $0.69,4.60$, and $6.75 \%$, respectively (Table 1 ). Cultivated land was the main land use type and the study area was representative of a typical agricultural landscape. About $81.11 \%$ of the gullies had developed on cultivated land and $97.39 \%$ of the shelterbelts were on cultivated land. The percentage of gullies and shelterbelts on other land use types was very low (Table 2), indicating that shelterbelts were mainly distributed in the cultivated land and that establishing blocks of shelterbelts can play a positive role in the prevention of gully erosion in the agricultural landscape.

\section{Effects of shelterbelts on gully erosion}

\section{Effect of slope}

As shown in Fig. 4, the densities of gullies and shelterbelts for different slope gradients ranged from 440.47 to $670.94 \mathrm{~m} \mathrm{~km}^{-2}$ and from 541.19 to $922.08 \mathrm{~m} \mathrm{~km}^{-2}$, respectively. Shelterbelt density decreased with increasing slope in a negative correlation $(y=-88.306 x+1027.5$, $R^{2}=0.9183, n=6, \mathrm{~d} f=5$ ). However, gully density increased with decreasing slope gradient in a positive correlation $\left(y=48.953 x+419.14, R^{2}=0.8847, n=6\right.$, $\mathrm{d} f=5$ ). Furthermore, slope and gully density for slope gradients of $<8^{\circ}$ were positively correlated $\left(y=73.478 x+366.09, R^{2}=0.9805, n=4, \mathrm{~d} f=3\right)$. For slopes of $<8^{\circ}$, gully density ranged from 440.47 to $651.18 \mathrm{~m} \mathrm{~km}^{-2}$, but on slopes $>8^{\circ}$, gully density was similar (Fig. 4). Therefore, slope can be seen as an important factor for gully formation when the slope angle is $<8^{\circ}$, but the impact of slope is weak when the slope is $>8^{\circ}$. Related studies in the adjacent county in the black soil region of northeast China obtained similar results, but also suggested that on slopes $>8^{\circ}$, other factors such as slope length have significant effect on gully erosion (Yan et al. 2006). In addition, Wang et al. (2012a) indicated that a critical slope angle exists for gully formation, and that for the black soil region of northeast China this slope is $5^{\circ}$. Therefore, it is clear that the influence of slope on gully formation is not constant and that further studies are required to identify the critical value of slope in different areas.

Figure 4 shows that with increasing slope gradient, the trend of shelterbelt density was the opposite to that of gully density. As shelterbelt density increased, gully density 

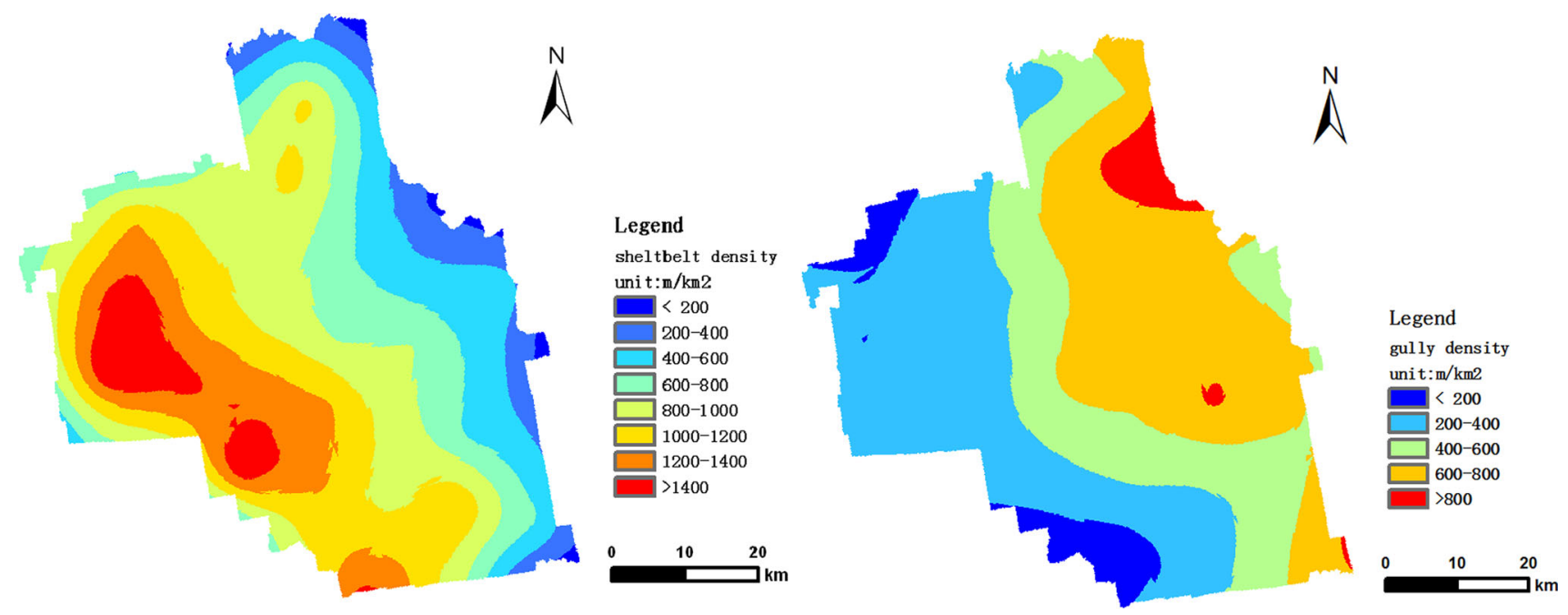

Fig. 3 Densities of farmland shelterbelts and gullies

Table 1 Classification of shelterbelt and gully densities

\begin{tabular}{lcrrrrr}
\hline Density $\left(\mathrm{m} \mathrm{km}^{-2}\right)$ & \multicolumn{3}{l}{ Shelterbelt } & & \multicolumn{2}{l}{ Gully } \\
\cline { 2 - 3 } & Area $\left(\mathrm{km}^{2}\right)$ & $(\%)$ & & Area $\left(\mathrm{km}^{2}\right)$ & $\%$ \\
\hline$<200$ & 24.35 & 0.72 & 185.06 & 5.46 \\
$200-400$ & 217.93 & 6.43 & 1152.89 & 34.02 \\
$400-600$ & 491.86 & 14.51 & 828.36 & 24.44 \\
$600-800$ & 522.63 & 15.42 & 1126.49 & 33.24 \\
$800-1000$ & 817.03 & 24.11 & 96.51 & 2.85 \\
$1000-1200$ & 661.59 & 19.52 & 0.00 & 0.00 \\
$1200-1400$ & 450.46 & 13.29 & 0.00 & 0.00 \\
$>1400$ & 203.64 & 6.01 & 0.00 & 0.00 \\
\hline
\end{tabular}

Table 2 Percentage of different land use types and percentages of gullies and shelterbelts in different land use types

\begin{tabular}{lrcc}
\hline Land use type & \multicolumn{1}{c}{$\%$} & Gully $(\%)$ & Shelterbelt $(\%)$ \\
\hline Cultivated land & 80.00 & 81.11 & 97.39 \\
Forest & 5.17 & 7.42 & 0.00 \\
Grassland & 2.78 & 3.43 & 0.60 \\
Water body & 0.69 & 0.00 & 0.01 \\
Built-up land & 4.60 & 2.11 & 1.48 \\
Marsh & 6.75 & 5.93 & 0.53 \\
\hline
\end{tabular}

decreased, suggesting that to some extent shelterbelts play a role in gully control. However, although there was little difference between shelterbelt density for slopes of $<1^{\circ}$ and $1^{\circ}-3^{\circ}\left(922.08\right.$ and $914.95 \mathrm{~m}^{\circ} \mathrm{km}^{-2}$, respectively), gully density increased from 440.47 to $502.42 \mathrm{~m}^{\circ} \mathrm{km}^{-2}$, respectively, indicating that slope had an important effect on gully formation. For slopes of $8-11^{\circ}$ and $>11^{\circ}$, shelterbelt density and gully density were 548.97 and 540.77 , and 670.84 and $672.87 \mathrm{~m} \mathrm{~km}^{-2}$, respectively, neither exhibiting significant change. These results show that for slopes $>8^{\circ}$, slope was not the most important factor in gully erosion.

In the black soil region of northeast China, slope angle and slope length are important factors governing gully formation. Slope angle affects runoff velocity and slope length affects runoff volume. As shown in Fig. 5, gully density was higher for slope lengths of 500-2000 m than for other slope lengths. For slope lengths $>2000 \mathrm{~m}$, gully density had a minimum value of $469.92 \mathrm{~m} \mathrm{~km}^{-2}$, indicating that slope lengths of 500-2000 m were prone to gully erosion. In this region, slope angle is generally between 1 and 8 and most of the land area is cultivated (Fan et al. 2004a; Cui et al. 2007). Long slope length causes large flow accumulation and concentrated runoff that lead to gully erosion (Fan et al. 2004a). However, in this region, slope lengths $>2000 \mathrm{~m}$ have slope angles $<1$ and most of the area is valley plain (Yan et al. 2007), which is not conducive to gully erosion.

\section{Distance}

Farmland shelterbelts in northeast China are an important part of the ecosystem that play crucial roles in the defense against natural calamities, wind erosion, and sand mobilization, while aiding water and soil conservation. One method to assess the ecological function of farmland shelterbelts is to study their effects over distance (Fan et al. 2002, 2004b; Su et al. 2012a). In the study area, the distances between farmland shelterbelts ranged mainly from 200 to $500 \mathrm{~m}$. For an adjacent area, Su et al. (2012a) reported that the distances between the farmland shelterbelts ranged from 284.6 to $472 \mathrm{~m}$, which is a similar 

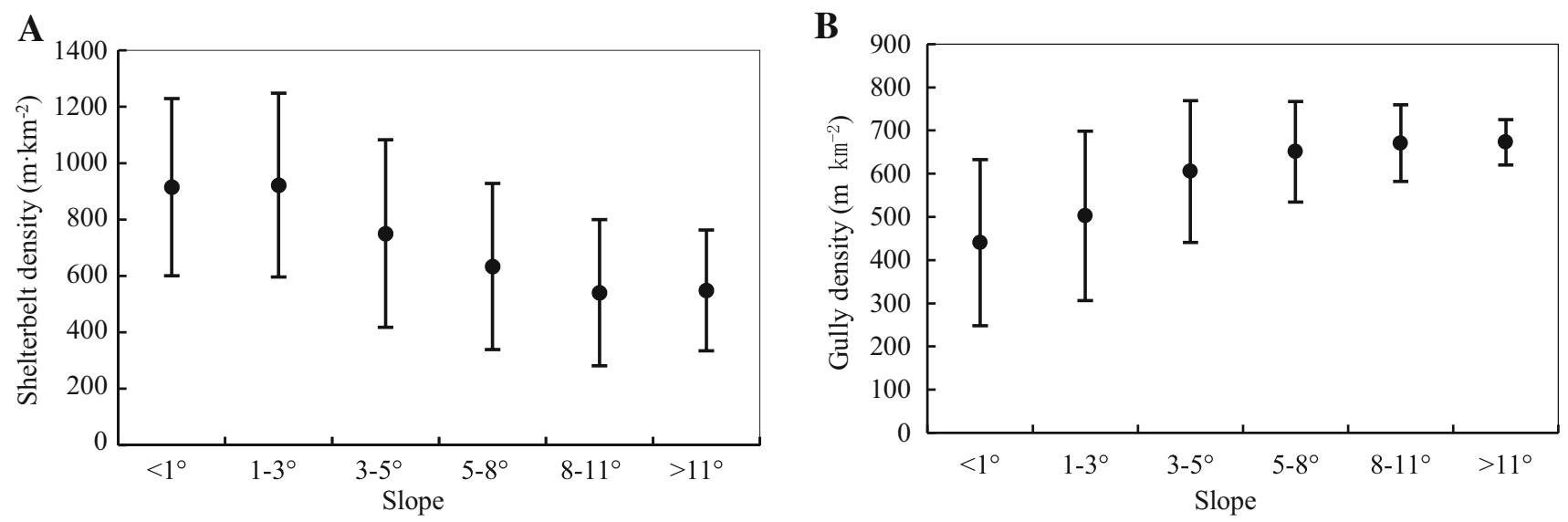

Fig. 4 Mean \pm standard error of gully and shelterbelt densities as functions of slope

distribution pattern. It was found that the gully density increased significantly with distance from the shelterbelt, meaning that the defense effect gradually weakened (Fig. 6). When the distance to the farmland shelterbelts was $<120 \mathrm{~m}$, gully density increased slightly, ranging from 419 to $428.14 \mathrm{~m} \mathrm{~km}^{-2}$. When the distance to the farmland shelterbelts was $120-240 \mathrm{~m}$, gully density increased from 441.66 to $464.98 \mathrm{~m} \mathrm{~km}^{-2}$, but when the distance was $>240 \mathrm{~m}$, gully density increased considerably to $504.80 \mathrm{~m} \mathrm{~km}^{-2}$. Thus, we conclude that the protection against gully erosion offered by farmland shelterbelts was not necessarily greater closer to shelterbelts. Within $120 \mathrm{~m}$ of farmland shelterbelts, the defense effect against gully erosion was consistent and very strong. For distances between 120 and $240 \mathrm{~m}$, the defense effect showed a linear decrease $\left(y=7.8289 x+433.97, R^{2}=0.9989, \quad n=4\right.$, $\mathrm{d} f=3$ ) and for distances $>240 \mathrm{~m}$, the defense effect was very weak.

Setting the correct distance between farmland shelterbelts in the black soil region of northeast China is very important in prevention and control of gully erosion. If the

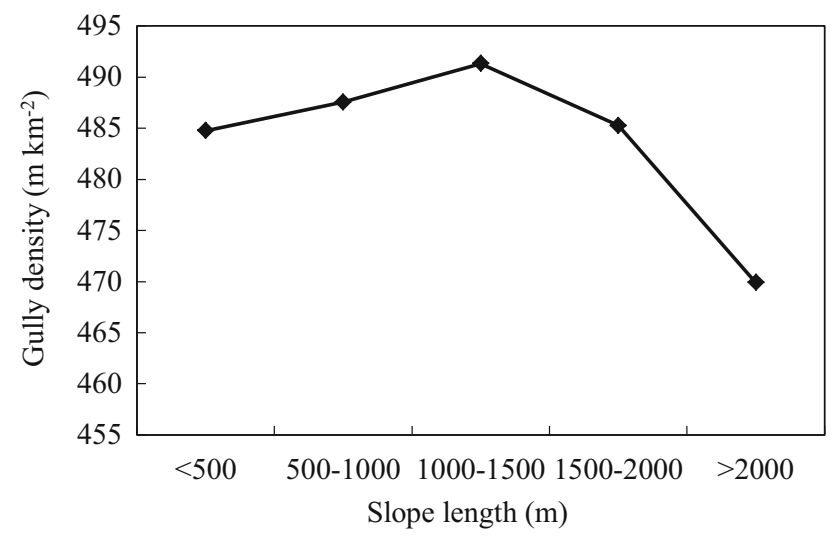

Fig. 5 Gully density as function of slope length distance is too great, there is no discernible defense effect. If the distance is too short, it represents a waste of labor and material resources and can affect crop growth. Based on the results of this study, we conclude that a distance of $120 \mathrm{~m}$ between farmland shelterbelts is suitable for the prevention and control of gully erosion. At present, the distances between farmland shelterbelts in the south and east regions were 200-300 m, too great for adequate gully control. Su et al. (2012b) revealed that the minimum distance between shelterbelts in Nenjiang County of the black soil region of northeast China is $267.7 \mathrm{~m}$ and that this distance is greater than the critical slope length for gully formation such that the farmland shelterbelts are not playing an effective role in controlling gully formation. This finding is consistent with the results of this study. The farmland shelterbelts in western, central, and northern regions exhibit serious fragmentation such that the distances between farmland shelterbelts are $400-600 \mathrm{~m}$, offering almost no defense against gully erosion. Therefore, increasing the planting density of the shelterbelts and

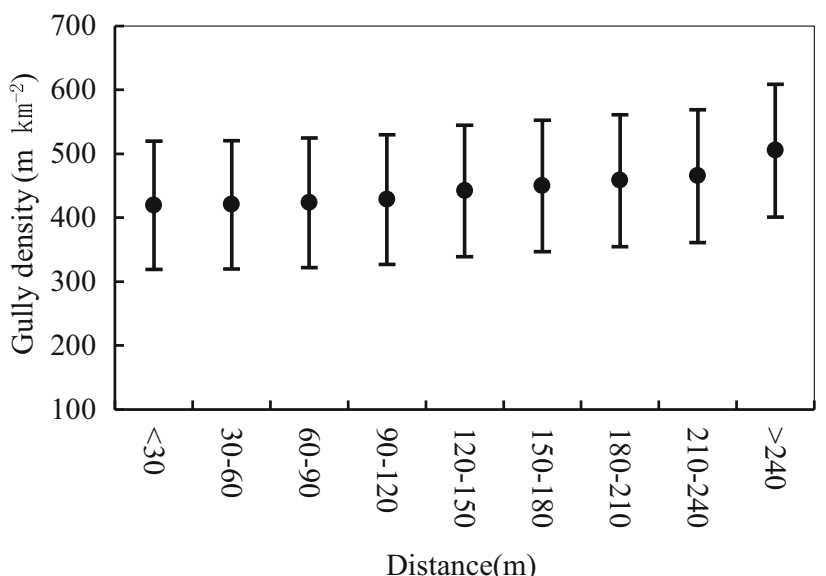

Fig. 6 Mean \pm standard error of gully density as function of distance to farmland shelterbelts 
reducing the distances between farmland shelterbelts are effective methods for the prevention and control of gully erosion.

\section{Shelterbelt density}

First, the shelterbelt density map was divided into nine grades according to the ranges of $<100,100-300$, $300-500, \quad 1300-1500$, and $>1500 \mathrm{~m} \mathrm{~km}^{-2}$. Then, the relationship between shelterbelt density and gully density was analyzed by overlaying the maps of shelterbelt density classification and gully density. Figure 7 shows that with an increase of shelterbelt density, gully density decreased from 702.26 to $263.69 \mathrm{~m} \mathrm{~km}^{-2}$. There was a linear relationship between shelterbelt density and gully density $\left(y=-60.496 x+807.56, R^{2}=0.9203, n=9, \mathrm{~d} f=8\right)$, indicating an obvious defense effect of shelterbelts against gully erosion. Furthermore, for shelterbelt densities of $500-1300 \mathrm{~m} \mathrm{~km}^{-2}$, shelterbelt density and gully density showed a highly linear relationship $\left(y=-113.75 x+777.31, R^{2}=0.9961, n=4, \mathrm{~d} f=3\right)$, indicating a more obvious defense effect of shelterbelts against gully erosion. The critical value of shelterbelt density was $1300 \mathrm{~m} \mathrm{~km}^{-2}$. At shelterbelt density $>1300 \mathrm{~m} \mathrm{~km}^{-2}$, gully density changed only slightly, decreasing from 321.68 to $315.56 \mathrm{~m} \mathrm{~km}^{-2}$. Thus, higher shelterbelt density did not bring greater improvement in the defense effect of farmland shelterbelts against gully erosion. The reasonable allocation and management of farmland shelterbelts is important for achieving optimal control and prevention of gully erosion, and conservation of resources. In the study area, gully density was very low for shelterbelt densities of $1100-1300 \mathrm{~m} \mathrm{~km}^{-2}$, which achieved an adequate defense effect. Therefore, the density of $1100-1300 \mathrm{~m} \mathrm{~km}^{-2}$ could be taken as a guideline planting density for farmland shelterbelts to achieve control of gully erosion.

We performed a multiple regression of gully $(y)$ as a function of slope $\left(x_{1}\right)$ and shelterbelt density $\left(x_{2}\right)$. Gully formation was positively correlated with slope, but negatively correlated with shelterbelt density $\left(y=-0.085+0.486 x_{1}-0.561 x_{2}, \quad R^{2}=0.493\right.$, $n=2311, \mathrm{~d} f=2310$ ). The interaction effect of the two factors was less than that of either slope or shelterbelt density alone, indicating that a comprehensive study of the factors that affect gully formation should be undertaken to achieve better understanding of the development process of gully erosion (Valentin et al. 2005; Wang et al. 2010).

For shelterbelt density of $500-700 \mathrm{~m} \mathrm{~km}^{-2}$, gully density appeared the trend of increase than the value ahead. This phenomenon was due to deforestation and farming in steep hilly areas. Natural gullying processes are

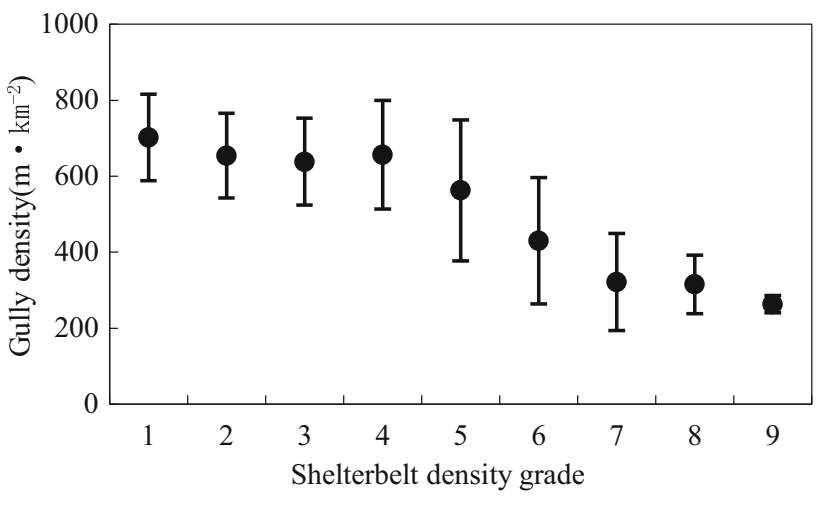

Fig. 7 Mean \pm standard error of gully density as function of shelterbelt density

accelerated by the intensification of farming systems (Valentin et al. 2005), and the depletion of soil organic matter reduces soil structural stability favoring crusting, runoff production, and gully erosion (Valentin 2004). Li et al. (2007) reported that the large area of sloping land and conversion of grassland to farmland within this region is the reason for the development and acceleration of gully formation. Yan et al. (2006) arrived at the same conclusion following a study in the adjacent Kedong and Baiquan counties. In mountainous regions, annual cropping has been reported to intensify rill and gully erosion processes (Chaplot et al. 2005), indicating that reasonable use of sloping land is crucial with regard to the prevention and control of gully erosion.

\section{Conclusions}

Compared with the number, density, length, and other parameters of farmland shelterbelts, the degree of gully erosion was serious. With increasing slope gradient, shelterbelt density decreased, but gully density increased, and for slopes $<8^{\circ}$, slope gradient was the principal factor affecting gully formation. Slope lengths of 500-2000 m were prone to gully erosion. Farmland shelterbelts can prevent and control gully erosion. The defense effect of shelterbelts was strong when the distance to farmland shelterbelts was $<120 \mathrm{~m}$. The defense effect was weaker when the distance was 120-240 m, and the defense effect was significantly weaker when the distance was $>240 \mathrm{~m}$. The optimal distance between farmland shelterbelts to prevent gully erosion was found to be $120 \mathrm{~m}$. We recommend a shelterbelt planting density of $1100-1300 \mathrm{~m} \mathrm{~km}^{-2}$ to have good effect on the control and prevention of gully erosion. In addition, the reasonable use of sloping land is critical for combating the problem of gully erosion. 


\section{References}

Bull LJ, Kirkby MJ (1997) Gully processes and modelling. Prog Phys Geogr 21(3):354-374

Capra A, Scicolone B (2002) Ephemeral gully erosion in a wheat cultivated area in Sicily (Italy). Biosyst Eng 83(1):119-126

Chaplot V, Coadou le Brozec E, Silvera N, Valentin C (2005) Spatial and temporal assessment of linear erosion in catchments under sloping lands of northern Laos. Catena 63:167-184

Chen P, Wan FX, Tang XL, Shen SG (2010) Planning of suburban shelter forest in Xukou Town of Suzhou City. J Beijing For Univ (Soc Sci) 3(1):90-94 (in Chinese with English abstract)

Cui M, Cai QG, Zhang YG, Fan HM (2007) Development of ephemeral gully during rainy season in the slope land in rollinghill black-soil region of Northeast China. Transa CSAE 23(8):59-65 (in Chinese, English abstract)

Dong YF, Wu YQ (2010) Short-term gully erosion at different places of bottom of gully using virtual erosion pins. Scientia Geographica Sinicae 30(6):892-897 (in Chinese, English abstract)

Fan ZP, Zeng DH, Zhu JJ, Jiang FQ, Yu XX (2002) Advance in characteristics of ecological effects of farmland shelterbelts. J Soil Water Conserv 16(4):130-133 (in Chinese with English abstract)

Fan HM, Cai QG, Wang HS (2004a) Condition of soil erosion in phaeozem region of Northeast China. J Soil Water Conserv 18(2):66-70 (in Chinese with English abstract)

Fan ZP, Zeng DH, Chen FS, Zhu JJ, Jiang FQ, Sha JG (2004b) Influence of shelterbelts structure on snow distribution pattern in shelternets in Northeast China. Chin J Appl Ecol 15(2):181-185 (in Chinese with English abstract)

Foster GR (2005) Modeling ephemeral gully erosion for conservation planning. Int J Sediment Res 20(3):157-175

Hauge CJ (1977) Soil erosion. Calif Geol 30:202-203

Krause AK, Franks SW, Kalma JD, Loughran RJ, Rowan JS (2003) Multi-parameter fingerprinting of sediment deposition in a small gullied catchment in SE Australia. Catena 53(4):327-348

Li XY, Wang ZM, Zhang SW, Yan YC (2007) Dynamics and spatial distribution of gully in the typical upland region of Northeast China. Scientia Geographica Sinicae 27(4):531-536 (in Chinese with English abstract)

Ma H, Zhou ZX, Wang PC, Wu CG, Xiao WF (2010) Spatial optimum allocation of shelterforest types in Three Gorges Reservoir Area based on multiple objective grey situation decision. Chin J Appl Ecol 21(12):3083-3090 (in Chinese, English abstract)

Meng LQ, Li Y (2009) The mechanism of gully development on sloping farmland in black soil area, Northeast China. J Soil Water Conservation, 23(1):7-11, 44 (in Chinese with English abstract)

Poesen J (1993) Gully topology and gully control measures in the European loess belt. In: Wicherek S (ed) 1992. Farmland erosion in temperate plains environment and hills. Proceedings international symposium on farmland erosion, saint-cloud, france. Elsevier, Amsterdam, pp 221-239

Poesen J, Nachtergaele J, Verstraeten G, Valentin C (2003) Gully erosion and environmental change: importance and research needs. Catena 50(2-4):91-133

Richard M, Robyn R (1990) The 'Three Norths' forest protection system-China. Agroforest. Syst. 10:71-88

Shen B, Fan JR, Pan QB, Hui LJ (2003) General situation of project for comprehensive control of soil erosion in black soil region of Northeast China. China Soil Water Conserv 11:7-8 (in Chinese with English abstract)

Shi CT, Wang EH, Gu HY, Chen XW (2010) Soil structure characters of different soil and water conservation plantations in typical black soil region. J For Res 21:151-154
Su ZL, Cui M, Fan HM (2012a) Effect of Shelterbelt distribution on ephemeral gully erosion in the rolling hill black soil region of Northeast China. Res Soil Water Conserv 19(3):20-23, 29 (in Chinese with English abstract)

Su ZL, Cui M, Fan HM (2012b) Optimization of shelterbelt distribution for the gully erosion control of cultivated slope land in rolling hill black soil region of Northeast China. Chin J Appl Ecol 23(4):903-909. (in Chinese, English abstract)

Sun JM, Liu TS (2001) Desertification in the Northeastern China. Quat Sci 21:72-78 (in Chinese with English abstract)

Torri D, Poesen J, Borselli L (1997) Predictability and uncertainty of the soil erodibility factor using a global dataset. Catena 31:1-22

Valentin C (2004) Overland flow, erosion and associated sediment and biogeochemical transports. In: Kabat P, Claussen M, Dirmeyer PA, Gash JHC, Bravo de Guenni L, Meybeck M, Pielke SrRA, Vorosmarty CJ, Hutjes RWA, Lutkemeier S (eds) 2003. Vegetation, water, humans and the climate. A new perspective on an interactive system. Global Change-The IGBP Series. Springer Verlag, Berlin, pp 317-322

Valentin C, Poesen J, Yong L (2005) Gully erosion: impacts, factors and control. Catena 63:132-153

Wang WJ, Zhang SW, Deng RX (2010) Gully status and relationship between gully and landscape pattern in Black Soil Area of Northeast China. Transa CSAE 26(2):109-115 (in Chinese with English abstract)

Wang WJ, Deng RX, Zhang SW (2012a) Spatial pattern change and topographic differentia of gully erosion in the type black soil area of northeast China during the past 40 years. Geogr Geo-Inf Sci 28(3):68-71 (in Chinese, English abstract)

Wang WJ, Zhang SW, Fang HY (2012b) Coupling mechanism of slope-gully system in type black soil area of Northeast China. J Nat Resour 27(12):2113-2122 (in Chinese, English abstract)

Wu YQ, Zheng QH, Zhang YG, Liu BY, Cheng H, Wang YZ (2008) Development of gullies and sediment production in the black soil region of northeastern China. Geomorphology 101:683-691

Yan YC, Zhang SW, Yue SP (2006) Application of corona and spot imagery on erosion gully research in typical black soil regions of Northeast China. Resour Sci 28(6):154-160 (in Chinese, English abstract)

Yan YC, Zhang SW, Yue SP (2007) Classification of erosion gullies by remote sensing and spatial pattern analysis in black soil region of eastern Kebai. Scientia Geographica Sinicae 27(2):193-199 (in Chinese with English abstract)

Yan YC, Zhang SW, Yue SP (2010) Dynamic change of hill slope and gully erosion in typical area of black soil region during the past 40 years. Trans CSAE 26(2):109-115 (in Chinese, English abstract)

Yang H (2001) Classification of gully in loess region of Jixian County, Shanxi Province. J Beijing For Univ 23(1):38-43 (in Chinese, English abstract)

Yu ZT, Wu YQ (2003) Causes and damages of gully erosion in black land. J Beijing Norm Univ (Nat Sci) 39(5):701-705

Zhang KL, Peng WY, Yang HL (2007a) Soil erodibility and its estimation for agricultural soil in China. Acta Pedo Sinica 44:7-13 (in Chinese with English abstract)

Zhang YG, Wu YQ, Liu BY, Zheng QH, Yin JY (2007b) Characteristics and factors controlling the development of ephemeral gullies in cultivated catchments of black soil region. Northeast China. Soil Till. Res. 96:28-41

Zhang YG, Wu YQ, Wang YZ, Liu BY (2008) Seasonal discrepancy of ephemeral gully erosion in Northeast China with black soils. Geogr Res 27(1):145-154 (in Chinese with English abstract) 